\title{
MAP OF NASCA GEOGLYPHS
}

\author{
$\underline{\text { K. Hanzalová1, K. Pavelka² }}$ \\ ${ }^{1}$ CTU in Prague, Civil Engineering Faculty, 16629 Prague 6, karolina.hanzalova@ fsv.cvut.cz \\ ${ }^{2}$ CTU in Prague, Civil Engineering Faculty, 16629 Prague 6, karel.pavelka@ gmail.com
}

KEY WORDS: geoglyphs, Nasca project, map, vectors, digital elevation model, satellite image

\begin{abstract}
:
The Czech Technical University in Prague in the cooperation with the University of Applied Sciences in Dresden (Germany) work on the Nasca Project. The cooperation started in 2004 and much work has been done since then. All work is connected with Nasca lines in southern Peru. The Nasca project started in 1995 and its main target is documentation and conservation of the Nasca lines. Most of the project results are presented as WebGIS application via Internet. In the face of the impending destruction of the soil drawings, it is possible to preserve this world cultural heritage for the posterity at least in a digital form.

Creating of Nasca lines map is very useful. The map is in a digital form and it is also available as a paper map. The map contains planimetric component of the map, map lettering and altimetry. Thematic folder in this map is a vector layer of the geoglyphs in Nasca/Peru. Basis for planimetry are georeferenced satellite images, altimetry is created from digital elevation model. This map was created in ArcGis software.
\end{abstract}

\section{INTRODUCTION}

\subsection{Maria Reiche}

Maria Reiche was born in Dresden (Germany) where her early interest for natural scientific observation began. She studied mathematics, physics, philosophy, pedagogy and geography. In 1932 she went to Peru. In 1941 Maria travelled t to Nasca for the first time. She should have confirmed Dr. Kosok's theory, that the lines are an astronomical calendar installation. She started her research work in the Nasca desert in 1946, because she wasn't allowed to leave the city Lima until the end of the Second World War. She investigated the Nasca drawings for more than 40 years and received an extensive help from the office for aerial photographs of the Peruvian air force (SAN). They enabled her many flights over the drawings, where she made valuable aerial photos. She succeeded common with her sister Renate to build a lookout tower at the Panamericana, from where you can see some figures and lines. Finally, the lines of the Nasca were set under protection of the UNESCO in 1995.

\subsection{Nasca project}

In 1994 the "Maria Reiche" Association was founded in Dresden for extension and continual science workflow in the Nasca region. In 1995 the Nasca project was initiated at the University of Applied Science in Dresden. The Nasca project's aims are: storage and preservation of the world culture heritage in digital form, preservation of data and resulting information, creating of digital thematic maps. Another aim of the project is to find if there is an astronomical caused construction scheme of the lines and figures. In this way it should be taken up and continued the work of Maria Reiche. There are theories which speak also about marking of subterranean water resources, ceremonial and religious signification, artistic expression or extra-terrestrial influence.
The Nasca project has organized several expeditions. The first expedition started in 1994. The ninth expeditions was organized last year in November.

\begin{tabular}{|l|c|}
\hline Data & Resolution \\
\hline Aerial photogrammetry & in the order of $\mathrm{cm}$ \\
Remote sensing: & $1 \mathrm{~m}$ \\
Ikonos & $0,6 \mathrm{~m}$ \\
Quickbird & $0,5 \mathrm{~m}$ \\
GeoEye & \\
DMT: & $90 \mathrm{~m}$ \\
SRTM & $15 \mathrm{~m}$ \\
From ASTER & \\
\hline
\end{tabular}

Table 1. Accuracy of the available data

\subsection{Data}

Practical solution how to capture the geographical information of this huge area to an adequate accuracy will be a photogrammetric data. Data collection is very important. There are 179 aerial black and white photos (1:10 000) of this area that were made during two photo flight mission in May 1997 and May 1998. About 150 images of a sightseeing flight were taken during expeditions in 2008 and 2010. Photogrammetric data covers only the main area of the Nasca desert. For this reason is important to use a satellite images. Ground control points are necessary to rectify these images. The orthorectified data can be used for the GIS data capture. The third important basis for this project is a digital terrain model. This is very useful layer. The first regional digital terrain model (DTM) had been worked out by digitizing contour lines and singles points by using existing topographical maps. Followed global DTM of 
the Shuttle Radar Topography Mission (SRTM). Accurate DTM was generated from photogrammetric aerial images. Another regional DTM was generated by using ASTER data. Within the TanDEM-X Mission, an even more precise global DTM will become available.

\section{MAP OF THE NASCA GEOGLYPHS}

\subsection{Geoglyphs}

The geoglyphs on the Nasca plain are very famous. Geoglyphs are created by removing the dark outer layer light so excelled surface. Due to the dry condition patterns persisted for centuries. Generally, geoglyphs are divided into three groups: drawings of animals or plants, geometric shapes, rays and beam center. Drawings of animals are the most famous e.g. monkey, spider, hummingbird, etc. The geometric shapes are elongated triangles and rectangles, spirals and zig-zag lines. Rays are narrow lines which are over hills and valley and many kilometres away.

Creating of Nasca lines map is very useful. It is important to document not only the famous drawings on the Nasca plain as monkey or spider, but also the simple lines or triangles.

\subsection{Creating of map}

The map contains planimetric component of a map, map lettering and altimetry. The map covers an area of about $50 \mathrm{~km}^{2}$. Basis for planimetry are georeferenced satellite images. There were used satellite images from Quickbird with resolution $0,6 \mathrm{~m}$ and the satellite images from GeoEye with resolution $0,5 \mathrm{~m}$. Ground control points were necessary to rectify these satellite images. Ground control points were measured by GPS during several expeditions in Peru. Accuracy of the ground control points is in order of $\mathrm{cm}$.

Altimetry of the map is created from a digital elevation model. A local digital terrain model was generated from photogrammetic aerial imagery with high accuracy. Images are not on the whole area. Depending on this fact, the map was made only for the area with elevation (see Figure 3.)

Processing of the map was created in ArcGis software. Thematic folder in this map is vector layer of geoglyphs in Nasca plain. The famous geoglyphs were measured by GPS during expedition in 2004. Vector layer of the geoglyphs was made on substrates of this measure and vectorization from georeferenced satellite images in Peruvian local coordinate system: PSAD56.

The map is in digital form and it is also as paper map.

\subsubsection{Distribution of geoglyphs on the map}

The geoglyphs were divided into several groups:

$\begin{array}{ll}\text { 1. } & \text { Lines } \\ \text { 2. } & \text { Figures } \\ \text { 3. } & \text { Closed areal shapes } \\ \text { 4. } & \text { Unclosed areal shapes }\end{array}$

The line is simple shape, sometimes several kilometres long. These shapes of geoglyphs are the largest group.

The figure is shape of some animal (e.g. Monkey), person (e.g. El Astronauto or Fisherman) or plants. This group is very famous. The shapes are very in size. For example Monkey is cca $120 \mathrm{~m}$ long, Condor is $150 \mathrm{~m}$ long and the Pelican is with beak cca $300 \mathrm{~m}$ long.

The closed areal shapes are large areas which have start and end. They are completed. In contrast are unclosed areal shapes.
They are also large but have not end or are connected to another shape. These last two groups include the largest shapes. Normally shapes are several hundred meters long.

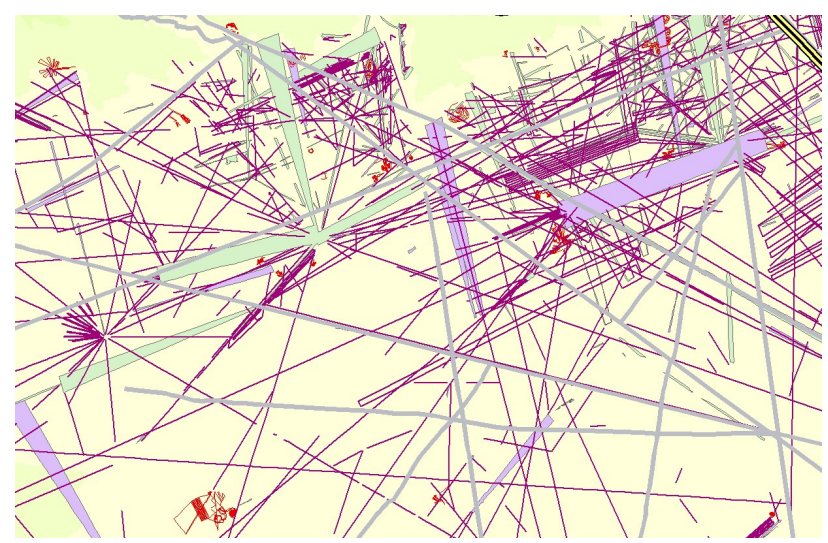

Figure 1. Cut from map a colors of geoglyphs: red - figures, purple - lines, purples area - closed areas shapes, green area unslosed areas shapes.

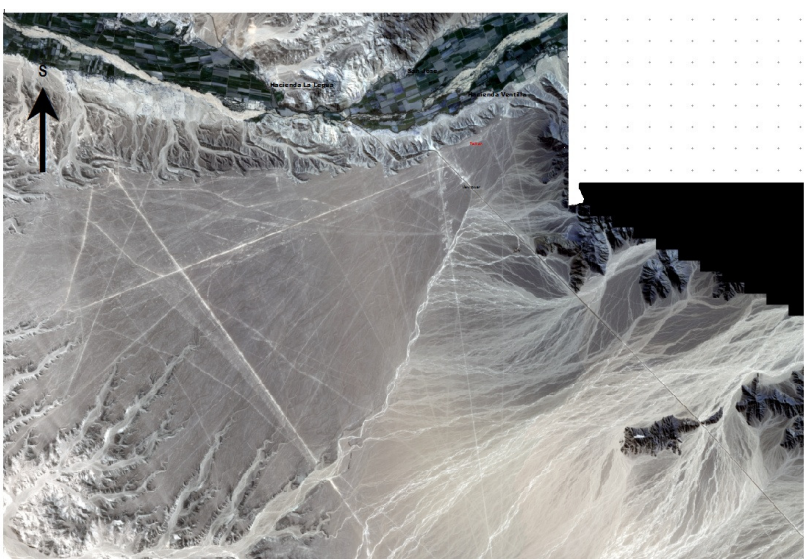

Figure 1. Under layer for creating the map -satellite image

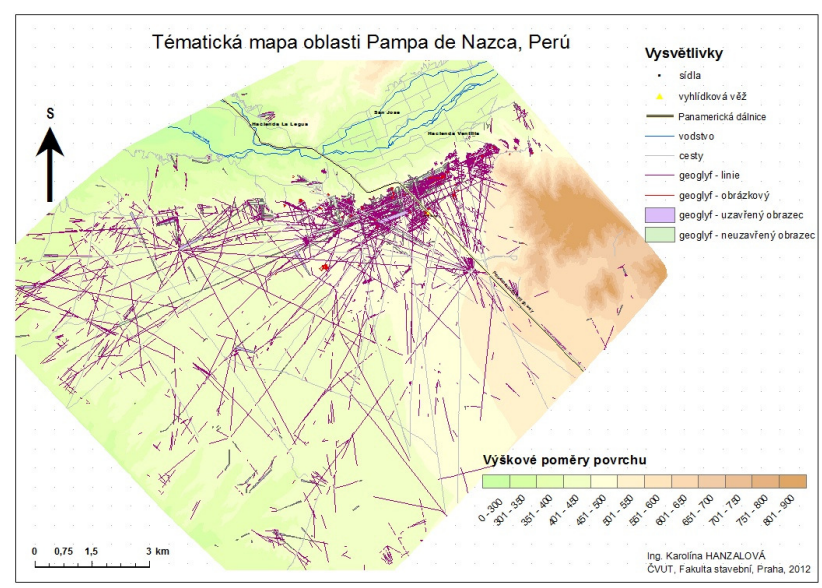

Figure 2. General view on the map of geoglyphs. 


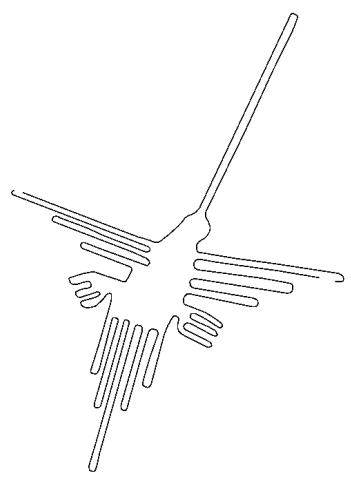

Figure 3. The most popular geoglyphs: Hummingbird, $95 \mathrm{~m}$ long

\section{REFERENCES}

Pavelka, K., Klokočník, J., Kostelecký, J., 2013. Astronomicko-historické otazníky Mezoameriky a Peru, Nakladatelství ČVUT Praha, 288p., v print.

Reiche, M., 1996, Mystery on the Desert Nazca. Peru, reedition by Assoc. M. Reiche for the Lines of Nasca, Nasca, Peru. 67 p.

Pavelka, K., Teichert, B., Richter, Ch. The Documentation of Geoglyphs and Petroglyphs in Nazca/Peru by Using Remote Sensing and Photogrammetry. In 13th Australasian Remote Sensing and Photogrammetry Conference. Sydney: ARSPC, 2006, pp. 225-228.

Pavelka, K., Klokočník, J. Nasca, Peru: Der Astronaut ist ein Fischer. Amerindian research. 2010, Jahr. 5, nr. 2, pp. 112-114. ISSN 1862-3867.

Johnson, D., 2009. Beneath the Nasca lines and other coastal geoglyphs of Peru and Chile, a book on CD, Pougkeepsie NY.

Hanzalová, K., 2008. Zpracování družicových a leteckých snímků z oblasti Nazca/Peru. ČVUT. FSV, Katedra mapování a kartografie, Praha.

Hanzalová, K., 2010. Verwendung der Aerophotogrammetrie und Fernerkundung für die Dokumentation der Geogplyphen undBildung der topographischen Karte in Nasca/Peru. ČVUT, FSV, Katedra mapování a kartografie, Praha.

\section{THANKS}

This work was created with the support of student grant competition 2011. 